PARLIAMENTARY NEWS

(October to December 1977)

(As reported to the Public Policy Committee)

\section{Mental Health Policy}

In written replies to questions dated 26 October, 14 November and 15 November, the DHSS poligy was again briefly set out-'the development of a range of local facilities which will eventually replace the present patterns of service'. Hospitals for the mentally ill were 'in general envisaged as being replaced by the new pattern', though their rundown or closure was not 'an end in itself'. The recent document The Way Ahead emphasized the high priority to be given to the new pattern. RHAs had now produced their first 'strategic plans' for action in the next ten years.

In this connection a written answer on 8 December stated that the proportion of psychiatric beds in general hospital units had risen from 5.8 in 1973 to $8 \cdot 1$ in 1975.

Another written answer (26 October) gave figures for a particular local authority (Lancashire) which may be of general application. Between 1974 and 1977 the number of hostels and 'independence units' for the mentally ill rose from 25 to 46 , but there are still no day centres in the area.

In his reply to the question relating to Friern Hospital (see below) Mr Ennals stated that in their Review of the Mental Health Act the Government were well aware of the genuine doubts that had been expressed concerning the care and treatment of informal patients, and would welcome comments from RHAs.

Another issue being considered in the review of the Act is that of consent to treatment, and proposals on this will be included in the forthcoming White Paper.

A very discouraging reply was given to a question relating to the transfer of patients from Special Hospitals. As before, the DHSS 'sees no quick solution to the problem'. Where there is opposition from the staff of the proposed receiving hospital it is necessary for the AHA to try to 'remove misunderstandings and prejudices' and to 'consider representations about safeguards for the staff'. (See also below under 'Mental Handicap').

\section{Individual Hospitals}

Holloway Sanatorium: The AHA is engaged in discussions about its future.

Hospitals in Northumberland: A reassuring reply was given to a question implying unfairness in the allocation of funds.
Friern Hospital: Mr Ennals welcomed and agreed with the statement by the RHA disowning the adverse allegations made by its monitoring team (which had been leaked to the Press). He regretted that the staff should have been exposed to speculation and comment as a result of these disclosures.

St Andrew's, Northampton: A question implying that the NHS was 'contributing to private medical care' at this hospital was answered to the effect that the AHA's contract made an essential contribution to NHS facilities in the area.

Mendip Hospital, Wells: The Member for the Wells Division, Mr R. Boscowen, brought up the question of this hospital's future in one of the Christmas Recess Adjournment Debates (16 December). A Discussion Document had been circulated by Somerset AHA in which it was suggested that the hospital might be closed by about the year I991. He stressed the importance of great care in assessing the needs of a catchment area and mentioned a number of factors that ought to be taken into account, including the effect on local employment. In reply, the Under-Secretary, Mr Deakins, again described at length the DHSS general policy and gave the usual assurance of 'no closure until full facilities are provided elsewhere'. He said that more rather than fewer staff would be needed in the new pattern of services.

\section{Mental Handicap}

In a fairly lengthy set of questions and supplementary questions on 22 November, Members voiced the anxieties of parents about the care of their mentally handicapped children after their own death. The reply was that residential places, in aggregate, were sufficient to meet expected needs for the next ten years, but these places should be redistributed. Local authorities had been asked to pay special attention to the needs of 16- to 25-year-olds. On 23 November further questions were asked on housing for the mentally handicapped, and Mr Ennals referred to the recent Consultative Document on Housing Policy.

An Adjournment Debate initiated by Mr A. L. Williams, Member for Hornchurch, Essex, brought out more fully the problem, referred to above, of the obstacles to the transfer of patients from Special Hospitals. The patient in question here had previously been under care in both the local mental 
illness and the local mental handicap hospital; he had been a patient at Rampton for seven years and two years ago had been recommended for transfer to a conventional hospital; but neither of the two local hospitals would agree to accept him. There was a conflict of opinion between consultants at the three hospitals, and also among other consultants who had been called in. But, in addition, there was a 'blanket ban' on patients from Special Hospitals imposed by staff at one of the local hospitals concerned, and also at others. The Minister regarded this as 'unfortunate and misconceived' but could not see any way of overcoming the obstacles other than by continuing efforts at persuasion. He added, however, that many Special Hospital patients were being transferred without any problem arising.

Alexander Walk

\section{DISTINGTION AWARDS: A NOTE FROM THE PRESIDENT}

For several years now the College, through two Special Committees, has made recommendations to the Distinction Awards Committee, and it is believed that this has been a very useful exercise. However, it is felt that there are misunderstandings and a lack of information, and I have been asked to clarify the position.

On a national basis the Distinction Awards Committee, currently chaired by Sir Stanley Clayton, receives advice from National Advisers in a specialty, of which there are two or three; Regional Advisers appointed by the Chairman of the Distinction Awards Committee, in consultation with the appropriate College, to advise the Committee on A, B or C Awards; and local G Award Committees quite independent of the Colleges, which consider $\mathbf{C}$ Awards. More recently, Sir Stanley Clayton has introduced new Regional Higher Awards Committees for A and B Awards. Members are appointed to these by invitation. The Distinction Awards Committee also receives unsolicited advice from a number of sources.

The College sends advice direct to the Distinction Awards Committee through its two Special Committees, the one advising on C Awards, and the other on A and B Awards. The Senior Officers of the College, the Chairmen of the Specialist Sections or the highest award holders in each specialty, and the National Advisers serve on the Special Committee which makes recommendations for A and B Awards. The membership of the $\mathbf{C}$ Awards Committee of the College includes the Senior Officers, the Chairmen of the Divisions and Specialist Sections and Groups, and the Regional Advisers to the Distinction Awards Committee. Sections or Divisions of the College are free to send advance proposals to either Special Committee. Before the Special Committees meet, lists of non-award holders are sent confidentially to all members so that they may consider them and take informal advice from their colleagues beforehand; because of the seal of confidentiality, lists of award holders cannot be made available before the meetings. Members of the Committees can only advise on awards not higher than their own, and at certain stages during the Committee proceedings some members may be required to withdraw.

Following the meetings of the College Special Committees, usually in July, citations are collected for all the names that are to be put forward, and these are sent to the Chairman of the Distinction Awards Committee as soon as they are available.

We believe that the College's involvement in making recommendations for Distinction Awards has been beneficial to the specialty, and that the position has improved since we have been doing this.

Any consultant who wishes to do so may send details of his own career direct to the Chairman of the Distinction Awards Committee, and if he has already done this he may update it by sending further particulars to that Committee. Details about one's own standing in relation to Distinction Awards should not be sent direct to the College.

W. Linford ReES

President 